\title{
Survey of schools' work with child and adolescent mental health across England: A system in need of support
}

\begin{tabular}{|c|c|}
\hline Journal: & Child and Adolescent Mental Health \\
\hline Manuscript ID & CAMH-OA-2015-0227.R1 \\
\hline Wiley - Manuscript type: & Original Article \\
\hline Date Submitted by the Author: & $\mathrm{n} / \mathrm{a}$ \\
\hline Complete List of Authors: & $\begin{array}{l}\text { Sharpe, Helen; UCL and Anna Freud Centre, Evidence Based Practice Unit; } \\
\text { University of Edinburgh } \\
\text { Ford, Tamsin; University of Exeter Medical School, Institute of Health and } \\
\text { Social Care } \\
\text { Lereya, Tanya; University College London, Evidence Based Practice Unit } \\
\text { Owen, Chris; UCL Partners, Schools Health and Wellbeing Research } \\
\text { Network } \\
\text { Viner, Russell; University College London, UCL Institute of Child Health } \\
\text { Wolpert, Miranda; Evidence Based Practice Unit }\end{array}$ \\
\hline Key Words: & Mental health, School, Intervention, Therapy \\
\hline Abstract: & $\begin{array}{l}\text { Background: With evidence of rising need around mental health in young } \\
\text { people, cuts in specialist health provision and increasing recognition of the } \\
\text { central role of schools in supporting young people with mental health } \\
\text { problems, it is important to understand the provision of mental health } \\
\text { support currently available in schools, the nature of the relationship with } \\
\text { health and other providers of child and adolescent mental health (CAMH) } \\
\text { services, and what are the key barriers to accessing support. } \\
\text { Method: The study was a convenience sample survey of } 577 \text { school staff } \\
\text { from } 341 \text { schools in England. Participants completed an online survey } \\
\text { about the provision of specialist mental health support in their school, } \\
\text { including what support is available, who provides it, and perceived barriers } \\
\text { to supporting the mental health of young people. Data were linked to } \\
\text { publicly available data on school characteristics. } \\
\text { Results: Over two thirds of schools reported having some specialist support } \\
\text { available, with specialist provision more common in secondary schools. } \\
\text { Staff training and whole school approaches were the most frequently } \\
\text { employed specific approaches. Support was most often provided by } \\
\text { educational psychologists, followed by counsellors. School staff particularly } \\
\text { valued support and feedback within the schools context. The most } \\
\text { frequently cited barrier to mental health support was the limited capacity } \\
\text { of specialist CAMH services. } \\
\text { Conclusions: The results suggest a need to enhance the availability of } \\
\text { specialist support for mental health both within schools and in CAMH } \\
\text { services. }\end{array}$ \\
\hline
\end{tabular}


Page 1 of 22 Child and Adolescent Mental

SCHOLARONE
Manuscripts

Page 1 of 22 Child and Adolescent Menta

SCHOLARONE
Manuscripts \\ Page 1 of $22 \quad$ Child and Adolescent Mental Health}

Manuscripts

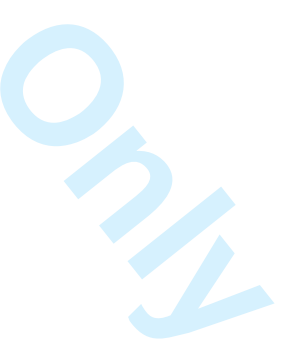


Running Head: Survey of schools' mental health work across England

Survey of schools' work with child and adolescent mental health across England:

A system in need of support

Helen Sharpe, PhD, Evidence Based Practice Unit (EBPU), University College London and the Anna Freud Centre, London, UK; The University of Edinburgh, Edinburgh, UK.

Tamsin Ford, PhD FRCPsych, University of Exeter Medical School, University of Exeter, Exeter, UK;

Suzet Tanya Lereya, PhD, Evidence Based Practice Unit (EBPU), University College London and the Anna Freud Centre, London, UK;

Chris Owen, MA, Schools Health and Wellbeing Research Network, UCL Partners;

Russell M. Viner, PhD, UCL Institute of Child Health, London, UK

Miranda Wolpert, DPsych, Evidence Based Practice Unit (EBPU), University College London and the Anna Freud Centre, London, UK

Correspondence: Dr. S. Tanya Lereya, Evidence Based Practice Unit (EBPU), University College London and the Anna Freud Centre, London, NW3 5SD, UK, Phone: +44 (0) 207443 2294, email: Tanya.Lereya@,annafreud.org

Word Count (excluding abstract): 4,578 
Running Head: Survey of schools' mental health work across England

\begin{abstract}
Background: With evidence of rising need around mental health in young people, cuts in specialist health provision and increasing recognition of the central role of schools in supporting young people with mental health problems, it is important to understand the provision of mental health support currently available in schools, the nature of the relationship with health and other providers of child and adolescent mental health (CAMH) services, and what are the key barriers to accessing support.
\end{abstract}

Method: The study was a convenience sample survey of 577 school staff from 341 schools in England. Participants completed an online survey about the provision of specialist mental health support in their school, including what support is available, who provides it, and perceived barriers to supporting the mental health of young people. Data were linked to publicly available data on school characteristics.

Results: Over two thirds of schools reported having some specialist support available, with specialist provision more common in secondary schools. Staff training and whole school approaches were the most frequently employed specific approaches. Support was most often provided by educational psychologists, followed by counsellors. School staff particularly valued support and feedback within the schools context. The most frequently cited barrier to mental health support was the limited capacity of specialist CAMH services.

Conclusions: The results suggest a need to enhance the availability of specialist support for mental health both within schools and in CAMH services. 
Running Head: Survey of schools' mental health work across England

\section{$\underline{\text { Key practitioner message }}$}

\section{What's known}

- Schools across England are a key site for support for mental health and wellbeing and teachers are the most commonly contacted mental health support.

- There have been challenges to communication and joint work between schools and CAMHS across England.

- One commonly cited view is that stigma about mental health is a key barrier to accessing support.

\section{What this study adds?}

- Staff training and whole school approaches were the most frequently employed specific approaches and support was most often provided by educational psychologists, followed by counsellors.

- The most frequently cited barrier to mental health support was the limited capacity of specialist CAMH services rather than attitudes towards mental health (stigma) associated with mental health.

- There is a need to enhance the availability of specialist support for mental health both within schools and in CAMH services.

- Current initiatives being trialled in the UK may suggest ways forward 
Running Head: Survey of schools' mental health work across England

\section{INTRODUCTION}

Ensuring the mental health needs of children and young people are met is an ongoing challenge both internationally and in England (Department of Health, 2015a). The most recent data suggest that 1 in 5 children with a significant mental health difficulty receive specialist help (Meltzer, Gartward, Goodman, \& Ford, 2000). In the light of evidence of rising levels of need (Fink et al., 2015) together with several years of reductions in specialist provision of child and adolescent mental health services (CAMHS) (Health Committee, 2014; YoungMinds, 2013), schools across England are increasingly a focus of attention as a key site for support for mental health and wellbeing (Durlak, Weissberg, Dymnicki, Taylor, \& Schellinger, 2011; Stallard, Simpson, Anderson, Hibbert, \& Osborn, 2007; Weare \& Nind, 2011). Teachers are the most commonly contacted mental health support (Ford, Hamilton, Meltzer, \& Goodman, 2007). Yet little is known about what support schools are seeking to provide to their students and pupils or what barriers there may be to their supporting accessing to specialist help. One commonly cited view is that stigma about mental health is a key barrier to accessing support (Gulliver, Griffiths, \& Christensen, 2010) leading to arguments that redressing this should be a key focus for resource allocation. There is emerging evidence that lack of national policy attention may also be a barrier to school mental health provision (Patalay et al., in press).

There is evidence of schools doing work to support mental health: systematic reviews of school-based mental health programs internationally suggest that there are programs that may enhance coping skills for stress (Kraag, Zeegers, Kok, Hosman, \& Abu-Saad, 2006) and positively impact on a variety of emotional and behavioural problems (Deighton et al., 2013; Fazel, Hoagwood, Stephan, \& Ford, 2014; Rones \& 
Running Head: Survey of schools' mental health work across England

Hoagwood, 2000; Wolpert, Humphrey, Belsky, \& Deighton, 2013). However, the relationship between these initiatives and targeted work for those with mental health problems remains unclear. There have been challenges to communication and joint work between schools and CAMHS (Fazel, et al., 2014; Pettit, 2003) which are likely to be exacerbated by current system changes. The education system in England is becoming one of the most diverse and devolved school systems in the developed world (Micklewright et al., 2014); NHS provision is being reorganised and reduced across the country and there are resource pressures, for example for local authorities who often acted as facilitator of joint working. Improving the relationship between schools and CAMHS is crucial to improve the provision of support for young people (Department of Health, 2015a) and current policy recommends there be a key member of staff in every school responsible for mental health and links with CAMHS (Department of Health, 2015a). However, there is limited up-to-date knowledge about the level of mental health provision in schools and current liaison with CAMHS.

The current survey aimed to engage with school staff to explore the following questions:

1) What specialist support is available for children and young people with mental health difficulties in schools in England and how does this vary across schools?

2) Who provides this specialist support in schools and how helpful do schools find this support?

3) What do school staff perceive as the key barriers to supporting young people with mental health difficulties?

\section{METHODS}


Running Head: Survey of schools' mental health work across England

\section{Design}

The study involved an opportunistic online survey of school staff working within England.

\section{Participants}

Any member of school staff working within England was eligible to participate. In total, 593 potential participants accessed the survey. Sixteen were excluded because they were based outside of England or provided no useable data, resulting in a final sample of 577. This included 348 respondents $(60 \%)$ who were members of their school's senior leadership team (SLT), inclusion support or pastoral managers; and $229(40 \%)$ respondents who were other members of school staff. Participants worked at 341 schools in England from 108 local authority areas. Nearly half of these schools $(48 \%, \mathrm{n}=164)$ were primary schools (equivalent to elementary schools, pupils aged

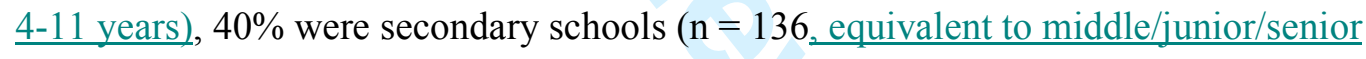
high schools, pupils aged 11-18 years) and the remainder were other types of school (e.g. all through schools, $\mathrm{n}=41)$. The majority were situated in urban areas $(81 \%, \mathrm{n}=$ 276), were non-fee paying $(94 \%, \mathrm{n}=319)$, and provided mainstream (rather than special) education $(85 \%, \mathrm{n}=290)($ see Table 1$)$.

\section{[INSERT TABLE 1]}

\section{$\underline{\text { Given the non-random sampling strategy, comparison to national data was used to }}$} examine the representativeness of the sample in this study. The current sample consisted of fewer primary schools and more secondary schools relative to England as a whole (see Table 1). The schools in the current sample were also less likely to provide mainstream education, more likely to have pupils with free school meal 
Running Head: Survey of schools' mental health work across England

eligibility (a measure of deprivation), and more likely be based in urban areas. The sample was representative of England's schools in terms of fee-paying status.

\section{Measures}

Data were collected using two bespoke questionnaires (see Supplementary document $1 \& 2$ for the full questionnaires). The questionnaire designed for the school leadership team and pastoral leads focused on overall school provision in relation to mental health support and relationship with CAMHS, while the other for any school staff focused on their knowledge and experience of support for mental health difficulties within the school. Please see Supplementary Table 1 for which of the questions were included in the SLT survey, which were included in the All Staff survey and which were included in both surveys.

\section{Procedures}

The surveys were hosted using a survey website (SurveyMonkey)-.as well as being advertised on social media. Using existing email groups and publically available

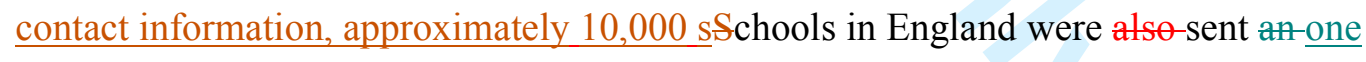
email advertising the survey. These emails did not go to individual school staff, but $\underline{\text { went to a single central school address (e.g. often the head teacher/principle or }}$ $\underline{\text { administrative team). No follow up emails were sent. The email invited the recipient }}$ to take part in the survey and/or pass the link on to colleagues. The link to the survey was also shared via social media (Facebook and Twitter) regularly for a period of approximately three weeks. and emailed to networks of colleagues working with schools to ask them to forward using publicly available contact details. 
Running Head: Survey of schools' mental health work across England

The study was exempt from formal ethical approval by University College London Research Ethics Committee due to being a non-sensitive, completely anonymous professional survey (written confirmation available).

\section{Analysis}

Data were analysed using STATA12 (StataCorp., 2011) and in a way which accounted for clustering of respondents within schools. The mean number of respondents per school was $3.66(\mathrm{SD}=4.62$, range $1-21)$, but approximately half of participants were the only respondent from their school $(48.79 \%, \mathrm{n}=263)$. Data were analysed in two ways: RQ1 and 2 were examined at the level of the school, and RQ3 was examined at the level of the individual staff members. For school-level research questions (RQ1 \& 2), aggregate school-level variables were created so schools with more respondents were not over-represented. For individual-level research questions (RQ3), survey methods (svy command) within STATA were used to account for this nested data structure. In order to investigate the variation in responses between different types of schools logistic regression was used.

The mean percentage of missing data per question was $16 \%$, ranging from $1 \%$ to $40 \%$ across questions. The amount of missing data was much higher in the All Staff survey $($ mean per question $=23 \%)$ compared with the SLT survey $($ mean per question $=5 \%)$. There was no difference between participants with high levels of missing data (i.e. who provided $\leq 2$ usable responses) and those with more complete data on any of the school characteristics (education phase, provision, fee-paying status, deprivation, urbanicity, relative size, $p \geq 0.14$ ). Thirty-eight (6\%) participants did not provide a school name, meaning that their data could not be matched to those from EduBase and could not be included in school-level analysis. In order to maintain as much data 
Running Head: Survey of schools' mental health work across England

as possible missing data were managed by pairwise deletion. In order to minimise the likelihood of Type I errors arising from multiple testing, alpha values were set to 0.01 .

\section{RESULTS}

\section{RQ1: What specialist support is available for young people with mental health} difficulties in schools in England and how does this vary with school factors?

School level data were analysed to investigate which support was available for young people. Sixty-eight percent $(\mathrm{n}=231)$ of schools reported having specialist support available. Secondary schools were more likely to report specialist support compared with primary schools $(\mathrm{OR}=2.78,95 \% \mathrm{CI}[1.66-4.64], \mathrm{p}=<0.001$; primary schools $57 \%, 79 \%$ secondary schools and $76 \%$ in other/all through schools). There were no differences based on urbanicity, fee-paying status, special provision, or level of deprivation $(\mathrm{p}=0.07-0.59)$.

The percentages of schools that reported using various approaches to support mental health are shown in Table 2. Most schools reported implementing staff training and whole school approaches, while only a small minority used themed support groups, mindfulness and peer support. The use of anger management $(\mathrm{OR}=2.19[1.28-$ $3.73], \mathrm{p}=0.004)$, themed support groups $(\mathrm{OR}=2.90[1.47-5.74], \mathrm{p}=0.002)$ and peer support $(\mathrm{OR}=3.86[2.07-7.20], \mathrm{p}<0.001)$ were all more common in secondary compared with primary schools. Family work was more common in urban schools $(\mathrm{OR}=0.40[0.21=0.74], \mathrm{p}=0.004)$ and mindfulness was more common in special schools $(\mathrm{OR}=2.74[1.35-5.57], \mathrm{p}=0.005)$. The use of whole school 
Running Head: Survey of schools' mental health work across England approaches was more common in schools with higher levels of deprivation $(\mathrm{OR}=$ $1.05[1.02-1.07], \mathrm{p}=<0.001)$.

\section{[INSERT TABLE 2]}

\section{RQ2: Who provides this specialist support for schools?}

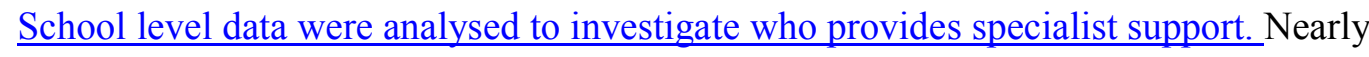
two thirds of schools $(62 \%, \mathrm{n}=162)$ reported having specialist support provided by counsellors, $20 \%$ by clinical psychologists, $81 \%$ by educational psychologists and $49 \%$ by other external agencies (e.g. drugs information). The availability of counsellors was more commonly reported in secondary schools compared with primary schools $(\mathrm{OR}=4.42[2.40-8.10], \mathrm{p}<0.001)$. Clinical psychologists were more available in special schools compared with mainstream schools $(\mathrm{OR}=2.73$ [1.30 - 5.72], $\mathrm{p}=0.008)$. Educational psychologists were more commonly drawn upon by primary school compared with other/all through schools (primary vs other $\mathrm{OR}=0.26[0.11-0.62], \mathrm{p}=0.003)$. Finally, the use of external agencies was more common in secondary schools compared with primary schools $(\mathrm{OR}=8.87$ [4.83$16.29], \mathrm{p}<0.001)$ and in school with higher levels of deprivation $(\mathrm{OR}=1.03[1.01-$ $1.05], \mathrm{p}=0.004)$.

When asked about the funding of external specialist support, $60 \%$ schools reported support provided by NHS CAMHS, $58 \%$ by the local authority (LA), $44 \%$ by private organisations, and $32 \%$ by the voluntary sector. Provision funded by the LA or private organisations was similar across schools, while provision by NHS CAMHS (OR = $4.81[2.62-8.78], \mathrm{p}<0.001)$ and the voluntary sector $(\mathrm{OR}=2.81[1.58-4.99], \mathrm{p}<$ 0.001) was more common in secondary schools compared with primary schools. 
Running Head: Survey of schools' mental health work across England

As shown in Table 3, schools were particularly positive about the helpfulness of specialist services they organise themselves within school and on the quality of the feedback received, when compared with external services in the local community (both NHS CAMHS and Other CAMHS services).

\section{[INSERT TABLE 3]}

\section{RQ3: What do school staff perceive as the key barriers to supporting young people with mental health problems?}

Lastly, in order to identify key barriers to support young people with mental health problems, data from individual staff members were analysed. The percentages of staff endorsing a range of potential barriers to the support of mental health in schools are shown in Table 4. The capacity of NHS CAMHS was the most frequently cited barrier, being endorsed as "very much a barrier" by nearly two thirds of staff (61\%). Similarly, the capacity of other mental health services, and the funding and the availability of specialists were also endorsed by over a third of staff. In contrast, links with agencies and attitudes towards mental health were rarely reported as being a perceived barrier. There was no significant difference in the likelihood of factors being reported as "very much a barrier" based on the participants" school type (phase of education, fee paying status etc.).

\section{[INSERT TABLE 4]}

\section{DISCUSSION}

In light of the level of mental health need being identified among children and young people (Fink, et al., 2015) and evidence of schools' rising concern about the challenges of meeting their needs (The Key, 2015) this school survey is particularly 
Running Head: Survey of schools' mental health work across England

timely. The findings provide tentative insight into the current provision of support for young people with mental health problems within school, what sort of support schools most value, and how well schools are linked in with specialist mental health services.

Over two thirds of schools reported having some form of specialist support available for their students with mental health problems. On the whole secondary schools reported having more specialist support available than primary schools. This may well reflect increased incidence of mental health problems during adolescence (Giedd, Keshavan, \& Paus, 2008), but the finding is particularly interesting in light of evidence that mental health support in primary school may be more effective than in later years (Wolpert et al., 2015).

\section{$\underline{\text { Although there were some differences between types of schools in the use of specific }}$} approaches to support students' mental health, in general differences between school types were notable in their absence. Differences between types of schools in the use of specific approaches to support students' mental health were notable in their absence. In generalMost, different types of schools tended to report using the same sorts of approaches, with staff training and whole school approaches emerging as the most commonly adopted strategies. These universal approaches have been found to be effective in promoting mental health and wellbeing, but may need to be complemented with targeted interventions, which typically produce larger effect sizes (Weare \& Nind, 2011). It is worth noting that some observed differences between schools may represent differences in need: for example, the greater use of external agencies and whole school approaches in schools with higher levels of deprivation may reflect the fact that children living in deprivation are at increased risk of developing mental health problems (Reiss, 2013). 
Running Head: Survey of schools' mental health work across England

The main specialist, external provision of mental health support in schools was by educational psychologists, particularly for primary schools. The importance of this group of professionals has been highlighted in other research (Vostanis, Humphrey, Fitzgerald, Deighton, \& Wolpert, 2013; Wolpert, et al., 2015). The second most common provider of mental health support in schools was counsellors. Recent guidance has focused on how best to ensure a motive role for counsellors in schools (Department of Health, 2015a). It is important to note in this regard that in England the majority of counsellors provide humanistic counselling (House \& Feltham, 2015) and it is hoped that in time the range of therapies available will be extended to include other evidence-based approaches in addition.

In terms of perceived helpfulness, schools were particularly positive about the input received from specialist services employed within their schools and on the quality of the feedback received from those services. Further work exploring what mechanisms underpin these positive experiences within schools may be useful to promote equivalent links between schools and external CAMHS services (both NHS and voluntary/independent sectors).

Finally, it was particularly strikingIt was notable that school staff did not highly rate attitudes towards mental health (stigma) or lack of knowledge as potential barriers to help. This finding may reflect the positive impact of recent anti-stigma campaigns such as Time to Change-(Evans-Lacko, Corker, Williams, Henderson, \& Thornicroft, 2014). The Time to Change (TTC) programme, launched in January 2009 (Henderson \& Thornicroft, 2009), aimed to make significant improvements across England in public attitudes and to achieve less discriminatory behaviour in relation to people with 
Running Head: Survey of schools' mental health work across England

mental illness. Awareness of Time to Change ranged between $38 \%$ and $64 \%$ and awareness of the campaign was consistently associated with better knowledge, attitudes and greater confidence to challenge mental health stigma (Evans-Lacko, Henderson, \& Thornicroft, 2013). This finding would be even more powerful if future work showed this reflected in the views of young people themselves (rather than just school staff as represented here). Notably, recent reviews continue to highlight stigma as a central barrier to help-seeking for young people (Gulliver, et al., 2010).

The key issue identified for schools was the In contrast, schøols did identify lack of capacity within specialist services as a key barrier to supporting their students with mental health problems. It has been noted that mental health services for children and young people is poorly funded and never given the priority it requires in the UK (Kennedy, 2010). And there are further reductions in specialist provision of child and

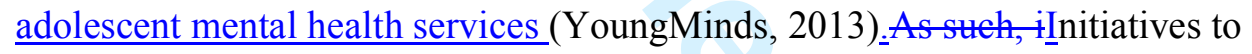
increase capacity are likely to be welcomed by schools.

$\underline{\text { In the light of these findings, recent initiatives policy and practice initiatives to }}$ support better links between schools and mental health providers, whilst recognising the limits and constrained resources that all groups are working within, are to be noted (Department of Health, 2015b) and put England in the forefront of such attempts across Europe (Patalay, et al., in press). For example, pilot work initiated by the Department for Education in collaboration with NHS England (which started after this survey was undertaken) seeks to improve understanding and collaborative working between schools and mental health providers by ensuring there is a named mental health lead in involved schools and greater clarity on referral pathways and processes with local specialist mental health providers (Department of Health, 2015b). Such 
Running Head: Survey of schools' mental health work across England

approaches may help to ensure that existing services are known about and accessed as appropriately and efficiently as possible.

\section{Study limitations}

It is important to understand these results within the context of a number of substantial limitations. First, the non-random sampling method did result in a sample that, although of reasonable size, was not fully representative of schools across England. It could be hypothesised that school staff that chose to respond had greater interest in mental health meaning the results may over-represent schools with more extensive support. The provisional findings from this survey suggest that future work using random sampling would be valuable. The survey necessarily used a bespoke questionnaire, and responses were constrained by the questions asked; we knownot know nothing-about the details of interventions used or their effectiveness, whether staff are reporting accurately, and closed questions on the survey may have overlooked important considerations.

\section{CONCLUSION}

This study confirm previous research showing that schools in England are a key site for mental health promotion and mental illness prevention in England (Ford, et al., 2007). Schools report using a range of approaches to support the mental health of their students and are particularly positive about the provision provided by specialists within their school. The central perceived barrier to being able to support students' mental health was not attitudes towards mental health problems, but rather the capacity of services. As such it seems particularly important to find ways to increase the availability of provision, both in the local area and within schools themselves, to support the mental health of young people. 
Running Head: Survey of schools' mental health work across England

Acknowledgements: We thank all the participating teachers for taking part in the survey.

Funding: This research received no specific grant from any funding agency in the public, commercial or not-for-profit sectors.

Conflicts of Interest: The authors have declared that they have no competing or potential conflicts of interest. Some of the co-authors (Tamsin Ford, Chris Owen, $\underline{\text { Russell Viner and Miranda Wolpert) are involved in providing mental health training }}$ to schools and child mental health services as part of a recent DfE commission.

Contributorship statement: Helen Sharpe: Planned and conducted the study, did the analyses and drafted the initial results \& methods section of the manuscript, reviewed and revised the manuscript. Tamsin Ford: Reviewed and revised the manuscript. Suzet Tanya Lereya: Reviewed and revised the manuscript. Chris Owen: Reviewed and revised the manuscript. Russell Viner: Conceptualised the study, reviewed and revised the manuscript. Miranda Wolpert: Oversaw the planning and development of the survey.-Drafted, drafted the initial introduction and discussion of the manuscript, reviewed and revised the manuscript. 
Running Head: Survey of schools' mental health work across England

\section{REFERENCES}

Deighton, J., Patalay, P., Belsky, J., Humphrey, N., Vostanis, P., Fugard, A., . . . Wolpert, M. (2013). Targeted mental health provision for children with behaviour difficulties in primary schools: Results of a national randomised trial. Psychology of Education Review, 37(2), 40-45.

Department of Health. (2015a). Future in mind: Promoting, protecting and improving our children and young people's mental health and wellbeing. London: HMSO.

Department of Health. (2015b). Hundreds of schools to benefit from $€ 3$ million investment in mental health in schools. Retrieved from https://www.england.nhs.uk/2015/12/mh-in-schools/

Durlak, J. A., Weissberg, R. P., Dymnicki, A. B., Taylor, R. D., \& Schellinger, K. B. (2011). The impact of enhancing students' social and emotional learning: A meta-analysis of school-based universal interventions. Child Development, 82(1), 405-432.

Evans-Lacko, S., Corker, E., Williams, P., Henderson, C., \& Thornicroft, G. (2014). Effect of the Time to Change anti-stigma campaign on trends in mentalillness-related public stigma among the English population in 2003-13: An analysis of survey data. Lancet Psychiatry, 1(2), 121-128.

Evans-Lacko, S., Henderson, C., \& Thornicroft, G. (2013). Public knowledge, attitudes and behaviour regarding people with mental illness in England 2009-2012. British Journal of Psychiatry, 202(s55), s51-s57.

Fazel, M., Hoagwood, K., Stephan, S., \& Ford, T. (2014). Mental health interventions in schools in high-income countries. Lancet Psychiatry, 1(5), 377-387.

Fink, E., Patalay, P., Sharpe, H., Holley, S., Deighton, J., \& Wolpert, M. (2015). Mental health difficulties in early adolescence: A comparison of two crosssectional studies in england from 2009 to 2014. Journal of Adolescent Health, 56(5), 502-507.

Ford, T., Hamilton, H., Meltzer, H., \& Goodman, R. (2007). Child mental health is everybody's business; the prevalence of contacts with public sectors services by the types of disorder among British school children in a threeyear period. Child and Adolescent Mental Health, 12, 13-20.

Giedd, J. N., Keshavan, M., \& Paus, T. (2008). Why do many psychiatric disorders emerge during adolescence? Nature reviews. Neuroscience, 9(12), 947957.

Gulliver, A., Griffiths, K. M., \& Christensen, H. (2010). Perceived barriers and facilitators to mental health help-seeking in young people: a systematic review. BMC Psychiatry, 10(1), 113.

Health Committee. (2014). Children's and adolescents' mental health and CAMHS, from http://www.publications.parliament.uk/pa/cm201415/cmselect/cmheal th/342/34202.htm

Henderson, C., \& Thornicroft, G. (2009). Stigma and discrimination in mental illness: Time to Change. Lancet, 373, 1928-1930.

House, R., \& Feltham, C. (2015). Counselling Psychology in the UK: A criticalhumanistic perspective. Self \& Society, 1-15. 
Running Head: Survey of schools' mental health work across England

Kennedy, I. ( 2010). Getting it right for children and young people. Overcoming cultural barriers in the NHS so as to meet their needs. London: Department of Health.

Kraag, G., Zeegers, M. P., Kok, G., Hosman, C., \& Abu-Saad, H. H. (2006). School programs targeting stress management in children and adolescents: A meta-analysis. Journal of School Psychology, 44(6), 449-472.

Meltzer, H., Gartward, R., Goodman, R., \& Ford, T. (2000). Mental health of children and adolescents in Great Britain. London: The Stationery Office.

Micklewright, J., Jerrim, J., Vignoles, A., Jenkins, A., Allen, R., Ilie, S., . . Hein, C. (2014). Teachers in England's secondary schools: evidence from TALIS 2013, from https://www.gov.uk/government/uploads/system/uploads/attachment data/file/322910/RR302 - TALIS report NC.pdf

Patalay, P., Giese, L., Stankovic, M., Curtin, C., Savka, N., Moltrecht, B., \& Gondek, D. (in press). Mental health provision in schools: priority, facilitators and barriers in 10 European countries. Child and Adolescent Mental Health.

Pettit, B. (2003). Effective Joint Working between CAMHS and Schools: Research report RR412. London: Department for Education and Skills.

Reiss, F. (2013). Socioeconomic inequalities and mental health problems in children and adolescents: A systematic review. Social Science \& Medicine, 90, 24-31.

Rones, M., \& Hoagwood, K. (2000). School-based mental health services: A research review. Clinical Child and Family Psychology Review, 3(4), 223241.

Stallard, P., Simpson, N., Anderson, S., Hibbert, S., \& Osborn, C. (2007). The FRIENDS emotional health programme: Initial findings from a schoolbased project. Child and Adolescent Mental Health, 12(1), 32-37.

StataCorp. (2011). Stata Statistical Software: Release 12. College Station, TX: StataCorp LP.

The Key. (2015). Summer Report: School leaders' concern about pupil wellbeing.

Vostanis, P., Humphrey, N., Fitzgerald, N., Deighton, J., \& Wolpert, M. (2013). How do schools promote emotional well-being among their pupils? Findings from a national scoping survey of mental health provision in English schools. Child and Adolescent Mental Health, 18(3), 151-157.

Weare, K., \& Nind, M. (2011). Mental health promotion and problem prevention in schools: What does the evidence say? Health Promotion International, 26, i29-i69.

Wolpert, M., Humphrey, N., Belsky, J., \& Deighton, J. (2013). Embedding mental health support in schools: learning from the Targeted Mental Health in Schools (TaMHS) national evaluation. Emotional and Behavioural Difficulties, 18(3), 270-283.

Wolpert, M., Humphrey, N., Deighton, J., Patalay, P., Fugard, A. J. B., Fonagy, P., . . Panos, V. (2015). An evaluation of the implementation and impact of England's mandated school-based mental health initiative in elementary schools. School Psychology Review, 44(1), 117-138.

YoungMinds. (2013). Local authorities and CAMHS budgets 2012/2013. London: YoungMinds. 
Running Head: Survey of schools' mental health work across England

Table 1: Comparison of sample in this study compared with all schools in England.

\begin{tabular}{|c|c|c|c|c|}
\hline & & $\begin{array}{c}\text { Sample in } \\
\text { this study } \\
n=341\end{array}$ & $\begin{array}{c}\text { All schools in } \\
\text { England } \\
n=\mathbf{2 6 , 4 5 8}\end{array}$ & $\begin{array}{l}\text { Current Sample vs. All schools in } \\
\text { England }\end{array}$ \\
\hline \multirow{3}{*}{$\begin{array}{l}\text { Education } \\
\text { phase }\end{array}$} & Primary $\%$ & 48.09 & 71.66 & $93.25, \mathrm{p}<.0001$ \\
\hline & Secondary $\%$ & 39.88 & 18.72 & $100.37, \mathrm{p}<.0001$ \\
\hline & Other/all through \% & 12.02 & 9.62 & $213.42, \mathrm{p}<.0001$ \\
\hline $\begin{array}{l}\text { Mainstream } \\
\text { provision }\end{array}$ & $\begin{array}{r}\text { \% schools providing } \\
\text { mainstream } \\
\text { education }\end{array}$ & 85.04 & 92.84 & $31.18, \mathrm{p}<.0001$ \\
\hline \multirow{4}{*}{ School size } & $\begin{array}{r}\text { Mainstream primary } \\
\mathrm{m}(\mathrm{sd})\end{array}$ & $\begin{array}{c}296.47 \\
(161.58)\end{array}$ & $\begin{array}{c}265.47 \\
(153.19)\end{array}$ & $\mathrm{t}(26797)=3.71, \mathrm{p}=.0002$ \\
\hline & $\begin{array}{r}\text { Mainstream } \\
\text { secondary } \mathrm{m}(\mathrm{sd})\end{array}$ & $\begin{array}{c}943.39 \\
(400.55)\end{array}$ & $\begin{array}{r}873.27 \\
(450.84)\end{array}$ & $\mathrm{t}(26797)=2.86, \mathrm{p}=.0043$ \\
\hline & $\begin{array}{r}\text { Mainstream other/all } \\
\text { through } \mathrm{m}(\mathrm{sd})\end{array}$ & $\begin{array}{c}867.31 \\
(435.92)\end{array}$ & $\begin{array}{c}478.08 \\
(433.23)\end{array}$ & $t(26797)=16.48, p=.0001$ \\
\hline & Special school m(sd) & $\begin{array}{c}96.59 \\
(78.85)\end{array}$ & $\begin{array}{c}70.04 \\
(61.51)\end{array}$ & $\mathrm{t}(26797)=7.89, \mathrm{p}=.0001$ \\
\hline $\begin{array}{c}\text { Free school } \\
\text { meal eligibility }\end{array}$ & $\begin{array}{l}\mathrm{m}(\mathrm{sd}) \text { in school } \\
\text { eligible for FSM }\end{array}$ & $\begin{array}{c}20.43 \\
(15.35) \\
\end{array}$ & $\begin{array}{c}16.76 \\
(13.83) \\
\end{array}$ & $\mathrm{t}(26797)=3.67, \mathrm{p}=.0001$ \\
\hline $\begin{array}{l}\text { Fee paying } \\
\text { status }\end{array}$ & $\%$ schools fee paying & 93.55 & 91.09 & $2.40, p=.111$ \\
\hline Urbanicity & $\begin{array}{r}\% \text { schools in urban } \\
\text { areas }\end{array}$ & 80.94 & 71.72 & $14.29, \mathrm{p}<.0001$ \\
\hline
\end{tabular}

1: Data based on all open schools excluding nurseries listed on EduBase (www.education.gov.uk/edubase) extracted on 11/09/15 
Running Head: Survey of schools' mental health work across England

Table 2: Percentage of schools reporting using each approach to support mental health, by school type

\begin{tabular}{|c|c|c|c|c|c|c|c|c|c|c|}
\hline \multirow[b]{2}{*}{ School type } & \multicolumn{10}{|c|}{ Approach } \\
\hline & $\begin{array}{c}\text { Staff } \\
\text { training }\end{array}$ & $\begin{array}{c}\text { Whole } \\
\text { school } \\
\text { approaches }\end{array}$ & $\begin{array}{c}\text { Learning in } \\
\text { the } \\
\text { curriculum }\end{array}$ & $\begin{array}{c}\text { Therapy } \\
\text { provision }\end{array}$ & $\begin{array}{l}\text { Nurture } \\
\text { groups }\end{array}$ & $\begin{array}{c}\text { Family } \\
\text { work }\end{array}$ & $\begin{array}{c}\text { Anger } \\
\text { management }\end{array}$ & $\begin{array}{c}\text { Peer } \\
\text { support }\end{array}$ & Mindfulness & $\begin{array}{c}\text { Themed } \\
\text { support } \\
\text { groups }\end{array}$ \\
\hline All schools & $79 \%$ & $68 \%$ & $59 \%$ & $57 \%$ & $55 \%$ & $54 \%$ & $40 \%$ & $27 \%$ & $25 \%$ & $20 \%$ \\
\hline Primary & $77 \%$ & $67 \%$ & $58 \%$ & $59 \%$ & $55 \%$ & $60 \%$ & $34 \%$ & $15 \%$ & $18 \%$ & $12 \%$ \\
\hline Secondary & $82 \%$ & $66 \%$ & $57 \%$ & $57 \%$ & $58 \%$ & $47 \%$ & $53 \%$ & $41 \%$ & $27 \%$ & $29 \%$ \\
\hline $\begin{array}{l}\text { Other/all } \\
\text { through }\end{array}$ & $81 \%$ & $75 \%$ & $69 \%$ & $50 \%$ & $44 \%$ & $50 \%$ & $25 \%$ & $31 \%$ & $50 \%$ & $28 \%$ \\
\hline Mainstream & $77 \%$ & $65 \%$ & $59 \%$ & $56 \%$ & $56 \%$ & $52 \%$ & $42 \%$ & $29 \%$ & $22 \%$ & $19 \%$ \\
\hline Special & $92 \%$ & $79 \%$ & $62 \%$ & $67 \%$ & $49 \%$ & $64 \%$ & $28 \%$ & $15 \%$ & $44 \%$ & $26 \%$ \\
\hline Low FSM ${ }^{1}$ & $72 \%$ & $50 \%$ & $53 \%$ & $50 \%$ & $53 \%$ & $48 \%$ & $38 \%$ & $25 \%$ & $19 \%$ & $16 \%$ \\
\hline Median FSM $^{1}$ & $76 \%$ & $61 \%$ & $56 \%$ & $54 \%$ & $55 \%$ & $52 \%$ & $39 \%$ & $25 \%$ & $20 \%$ & $18 \%$ \\
\hline High FSM $^{1}$ & $83 \%$ & $85 \%$ & $52 \%$ & $67 \%$ & $62 \%$ & $63 \%$ & $43 \%$ & $24 \%$ & $26 \%$ & $25 \%$ \\
\hline Non-fee paying & $79 \%$ & $68 \%$ & $59 \%$ & $59 \%$ & $57 \%$ & $55 \%$ & $48 \%$ & $26 \%$ & $25 \%$ & $22 \%$ \\
\hline Fee paying & $73 \%$ & $55 \%$ & $64 \%$ & $18 \%$ & $9 \%$ & $18 \%$ & $0 \%$ & $45 \%$ & $36 \%$ & $0 \%$ \\
\hline Urban & $79 \%$ & $68 \%$ & $58 \%$ & $60 \%$ & $56 \%$ & $58 \%$ & $41 \%$ & $25 \%$ & $24 \%$ & $21 \%$ \\
\hline Rural & $77 \%$ & $64 \%$ & $62 \%$ & $47 \%$ & $53 \%$ & $35 \%$ & $38 \%$ & $32 \%$ & $30 \%$ & $17 \%$ \\
\hline
\end{tabular}

Note: Differences between types of schools in the percentage reporting using an approach that are significant at $\mathrm{p}<0.01$ are bolded.

1: Note that analyses are calculated with $\% \mathrm{FSM}$ as a continuous predictor. For comparison purposes we present percentages based on predicted probabilities for the $10^{\text {th }}$ percentile of $\%$ FSM eligibility for 'low' FSM, the $50 \%$ percentile for 'median' FSM, and the $90^{\text {th }}$ percentile for 'high' FSM. These percentiles are based on national data (www.education.gov.uk/edubase). 
Child and Adolescent Mental Health

Page 22 of 22

Running Head: Survey of schools' mental health work across England

Table 3: Schools' perceptions on the helpfulness and quality of feedback from mental health services

\begin{tabular}{rccc}
\hline $\begin{array}{r}\text { Helpfulness of } \\
\text { services }\end{array}$ & $\begin{array}{c}\text { Specialist help in } \\
\text { school } \\
(\mathbf{n}=\mathbf{2 4 1})\end{array}$ & $\begin{array}{c}\text { IHS CAMUS } \\
(\mathbf{n}=\mathbf{2 4 9})\end{array}$ & $\begin{array}{c}\text { Other CAMHS } \\
\text { (voluntary/private) } \\
(\mathbf{n}=\mathbf{2 1 9})\end{array}$ \\
\hline $\begin{array}{r}\text { Helped } \\
\text { Neutral }\end{array}$ & $84 \%$ & $57 \%$ & $64 \%$ \\
Made things & $16 \%$ & $37 \%$ & $34 \%$ \\
worse & $0 \%$ & $6 \%$ & $2 \%$ \\
\hline Feedback from & $\begin{array}{c}\text { Specialist help in } \\
\text { school } \\
\text { services }\end{array}$ & $\begin{array}{c}\text { NUS CAMUS } \\
(\mathbf{n = 2 3 8 )}\end{array}$ & $\begin{array}{c}\text { Other CAMHS } \\
\text { (voluntary/private) } \\
(\mathbf{n}=\mathbf{2 2 0})\end{array}$ \\
\hline $\begin{array}{c}\text { Good } \\
\text { Poor }\end{array}$ & $70 \%$ & $39 \%$ & $48 \%$ \\
Not aware of any & $18 \%$ & $48 \%$ & $28 \%$ \\
feedback & $12 \%$ & $12 \%$ & $24 \%$ \\
\hline
\end{tabular}


Running Head: Survey of schools' mental health work across England

Table 4: Perceived barriers to supporting mental health in schools

\begin{tabular}{|c|c|c|c|c|c|}
\hline Barrier $(n=332-342)$ & $\begin{array}{l}\text { Not at } \\
\text { all }\end{array}$ & A little & Somewhat & $\begin{array}{c}\text { Quite a } \\
\text { lot }\end{array}$ & $\begin{array}{l}\text { Very } \\
\text { much }\end{array}$ \\
\hline $\begin{array}{r}\text { Capacity of NHS } \\
\text { CAMHS }\end{array}$ & $3 \%$ & $7 \%$ & $13 \%$ & $17 \%$ & $61 \%$ \\
\hline $\begin{array}{l}\text { Capacity of other } \\
\text { CAMHS services }\end{array}$ & $4 \%$ & $9 \%$ & $23 \%$ & $25 \%$ & $38 \%$ \\
\hline Funding & $4 \%$ & $13 \%$ & $22 \%$ & $24 \%$ & $37 \%$ \\
\hline Availability of specialists & $6 \%$ & $8 \%$ & $23 \%$ & $26 \%$ & $37 \%$ \\
\hline Lack of national policy & $4 \%$ & $14 \%$ & $22 \%$ & $27 \%$ & $33 \%$ \\
\hline School staff capacity & $6 \%$ & $11 \%$ & $22 \%$ & $30 \%$ & $31 \%$ \\
\hline $\begin{array}{r}\text { Knowing what support } \\
\text { is available }\end{array}$ & $7 \%$ & $13 \%$ & $28 \%$ & $25 \%$ & $27 \%$ \\
\hline $\begin{array}{r}\text { Attitudes towards } \\
\text { mental health }\end{array}$ & $20 \%$ & $22 \%$ & $27 \%$ & $17 \%$ & $14 \%$ \\
\hline Links with agencies & $11 \%$ & $15 \%$ & $34 \%$ & $28 \%$ & $11 \%$ \\
\hline
\end{tabular}

